\title{
Nieto, Agustín (2018). Entre anarquistas y peronistas. Historias obreras a ras del suelo. Buenos Aires, Imago Mundi/Ediciones CEHTI, 352 p.
}

\author{
Facundo Iturburu \\ iturburufacundo@gmail.com \\ GIMSSPAM, CEHis, Facultad de Humanidades, \\ Universidad Nacional de Mar del Plata, Argentina
}

Recepción: 17 Marzo 2020

Aprobación: 12 Agosto 2020

Publicación: 13 Noviembre 2020

Cita sugerida: Iturburu, F. (2020). [Revisión del libro Entre anarquistas y peronistas. Historias obreras a ras del suelo por A. Nieto]. Anuario del Instituto de Historia Argentina, 20(2), e131. https://doi.org/10.24215/2314257Xe131

La conflictividad laboral de principios de siglo en el puerto de Mar del Plata llevó a Agustín Nieto a indagar en la formación de la clase obrera de la industria del pescado local. La experiencia de clase a ras del suelo perseguida por Nieto en la tesis doctoral de la que emerge este libro, expresa las luchas en las fábricas y los ministerios, en las calles y los tribunales, en la prensa y en los hogares. El autor reconstruye trayectorias, voces y prácticas obreras poco exploradas, a la vez que propone un ejercicio de reflexión teórica y metodológica sobre su campo de estudio, desde una mirada que parte del marxismo y se complementa con aportes bibliográficos de otros enfoques teóricos.

El autor de esta obra entiende la construcción de comunidades obreras como condición necesaria para las acciones de resistencia a la explotación capitalista. No equipara cantidad creciente de huelgas a mayor grado de combatividad, sino que expone microconflictos propios de la experiencia de clase de sujetos atravesados por relaciones de poder, cuyos avances y retrocesos sólo pueden contemplarse de manera situada, a ras del suelo. Esta perspectiva es enriquecedora, aunque continúa abogando en una historiografía que se focaliza en la noción de lucha por sobre otras facetas de la vida de los/as trabajadores/as. En ese sentido, se presenta la conformación de un sindicalismo contestatario en la industria del pescado a partir de la activación militante anarquista que incentivó la toma de conciencia proletaria, identificación que el marxismo privilegia por sobre 
otras posibles. Si la conciencia de clase implica necesariamente la filiación a determinadas ideas políticas y no a otras es un debate de larga data que está lejos de saldarse.

Entre anarquistas y peronistas... se estructura en cinco capítulos compuestos por numerosos apartados. Las notas a pie de página y los cuadros y tablas expuestos complementan la narración para facilitar su comprensión. La descripción inicial de las características del mercado y del proceso de trabajo ictícola contextualizan la conflictividad transversal a la investigación. El historiador enfatiza, además, en un elemento poco considerado: la doble explotación de la mujer (patronal y patriarcal), su faceta gremial y su impacto en el accionar de sus pares varones. La cuestión de género complejiza el abordaje de una cultura sindical en constante reformulación.

La conservación de documentos de las cámaras empresariales y de parte del gremialismo pesquero facilita el armado de un relato complejo, en el que se entrecruzan otras fuentes como diarios, publicaciones político-partidarias, archivos policiales, entrevistas orales, etc. Este "trabajo de hormiga" se destaca independientemente de las discusiones que habilita la interpretación del autor, quien privilegia la exposición de la tensión constante en diferentes escenarios debido al incumplimiento patronal de los convenios colectivos. Nieto narra las motivaciones, las acciones, las perspectivas de las clases en conflicto e incluso las divergencias dentro del anarquismo y del empresariado.

En términos pedagógicos se observa una recurrente búsqueda de explicar las decisiones teóricometodológicas (como el uso de la equis por el lenguaje inclusivo) y los conceptos utilizados (ras del suelo, experiencia, fuerzas sociales obreras, etc.), construyendo una literatura que toma elementos de perspectivas como los estudios de género o los estudios locales, siempre en el marco general de la teoría social marxista en clave thompsoniana.

Las medidas de fuerza a las que la historiografía principalmente ha prestado atención son los paros y las huelgas. En esa línea, Nieto recompone la trascendencia de la huelga de 1942 en la industria ictícola de conservas como mojón en la lucha contra los bajos salarios y las malas condiciones de trabajo. A partir de la creación del fuero laboral en 1948, la disconformidad obrera se manifestó también en los estrados de los nuevos Tribunales del Trabajo, "imaginados y diseñados por las elites estatales del peronismo como un espacio propicio para la normalización de la conflictividad laboral” (p. 158). Aquí la propuesta de Nieto es innovadora ya que da cuenta de este nuevo escenario que los/as trabajadores/as con su capacidad de agencia supieron apropiarse, por ejemplo, realizando demandas colectivas, a contramano de lo estipulado por la normativa. Mediante la lectura de las sentencias judiciales se logran rescatar las formas "silenciosas" u "ocultas" de lucha como el sabotaje o el hurto presentes aun cuando no hay medidas de fuerza tradicionales.

Nieto introduce el concepto de fuerzas sociales obreras para superar la visión dicotómica que enfrenta dirección y bases y así abordar los períodos de disputa intersindical. Durante la proscripción del peronismo y especialmente por el crecimiento de la industria del filet en los años sesenta la geografía industrial del puerto local se modificó; las/os fileteras/os debieron convivir con un mercado de trabajo desregulado y en peores condiciones que las del sector conservero. Estos rasgos, al extenderse en el tiempo, "fueron configurando un ambiente propicio para la organización gremial" (p. 220) y, en palabras del autor, el germen de una identidad perdurable en sus obreros/as. Las protestas contra la sed de ganancias del capital tuvieron un carácter polimorfo. Por ello reconstruye desde historias mínimas de resistencia y trayectorias de militancia (con las demandas judiciales como "punta de hilo") hasta diatribas dialécticas entre sectores enfrentados del sindicalismo en el marco de las discusiones por los convenios colectivos.

Otra idea que emerge de la investigación sobre la industria ictícola marplatense entre los años cuarenta y sesenta es que la militancia gremial anarquista no finaliza abruptamente en los años treinta, como sostienen posturas historiográficas y políticas más tradicionales sobre el tema. Para llegar a esa conclusión, en el libro se describen el poderío anarquista alcanzado por medio de una lucha intransigente a principios de la década del cuarenta, sus vaivenes durante el peronismo, sus intentos de reinstalación tras el golpe militar de 1955 y su nueva recaída a mediados de los años sesenta. 
Por último, diremos que Entre anarquistas y peronistas... es un libro que puede interesar a quienes anhelen mantener "en constante movimiento" la discusión sobre "la cocina" de la actividad historiográfica. Desde el estudio de prácticas obreras históricas y espacialmente situadas, Agustín Nieto propone una manera de hacer historia de la clase trabajadora que remoce su propia tradición, buscando innovar y repensar la propia práctica, debatiendo sobre las escalas de análisis o la interpretación de las fuentes, sin perder de vista la vinculación de ese pasado con la actualidad, en un camino no lineal donde lo transversal, desde su mirada, es la lucha de los sectores subalternos contra la explotación en sus distintas facetas. 